\title{
Defosilization of /æ/ Phoneme Pronunciation of Non-native EFL Teachers
}

\author{
Ayhan Kahraman \\ Dumlupinar University, Kütahya, Turkey \\ Email: ayhan@dumlupinar.edu.tr
}

\begin{abstract}
The literature asserts that when a foreign language is learned after puberty, the fossilized pronunciation problems of adult FL learners cannot be remedied. However, to the best of knowledge there was no empirical evidence to support this belief. Therefore, the present study aimed to investigate whether or not non-native English teachers' fossilized pronunciation mistakes on /a/ vowel phoneme of the British English language can be cured through treatment. First, a diagnostic test as a pre-test was used before the treatment phase to identify participants' pronunciation problems and the same test was repeated after treatment to check out any difference. As the data revealed from repeated measurements, the Wilcoxon signed-rank test was used and the results displayed a significant difference $(z=-3.527, p<.05)$. That is, the application of the cure programme developed using the audio-articulation method facilitated participant teachers to cure their pronunciation problem on /a/ vowel phoneme of the British English. In brief, this study has proved this case and cured non-native English teachers' problem. All in all, this study recommends non-native language teachers to improve language teaching materials with explicit pronunciation exercises especially for adult learners using similar methods.
\end{abstract}

Index Terms - fossilized mistakes, pronunciation errors, mistake eraser, fossilization.

\section{INTRODUCTION}

The hypothesis that there is a critical or sensitive period for first language acquisition plays an important role in the field during the last 50 years. The critical period for learning is defined in biology by Colombo (1982) as "a time during the life span of an organism in which the organism may be affected by some exogenous influence to an extend beyond that observed at other times" (p. 261). During this period, there seems to be sensitivity to stimuli and after this period there is a non-linear decline in sensitivity. That is, the first few years of life is the crucial time in acquiring the first language if the needed input is provided. Lenneberg (1964) asserted that the crucial period of language acquisition begins at age two and completed around puberty. And if no language is learned before this age, it could never be learned in a normal functional sense. For instance, "the wild child" Genie has always been an extreme example. As she was found, she was thirteen years old and appeared to be entirely without language. The theory was tested but she was unable to acquire her first language completely. Actually, this evidence makes the issue more complicated for adult foreign language learners since first they have passed the critical period and second they do not have the chance to share the same acquisition/learning setting when compared to first language learners.

Since the 1960s much research has been also done on the age factor in foreign language learning. Nevertheless the results were contrary to the common misbelieve and supported the generalization that adults in a formal learning setting learn faster than children. It does not appear applicable to the pronunciation, however. Despite the fast progression in grammar, adult learners rarely achieve a native-like accent. Selinker (1972) goes further and asserts that once language learners have passed the critical period, their pronunciation becomes inevitably fossilized. This belief is supported by an extreme but widely accepted Kissenger effect sample. It is known that although Henry Kissenger, German-born American political scientist and diplomat, had magnificent and fluent control on the English language, he had a German accent while speaking English.

Assertions such as Selinker's and extreme samples like Kissenger effect has set ground for many researchers' ideas as it is too difficult or impossible to change pronunciation once a certain age of pronunciation has been reached. However they are not able to put on view the impossibility of defosilization. That is, although it is very hard to change learners' pronunciation after the critical or sensitive period, it does not mean that there is no rehabilitation for this deficiency. For example Acton (1984) states that pronunciation deficiencies frequently seem to be rigid or inflexible. Nevertheless, he suggests teachers some patience and learners a concerted effort. Since, the learner, learners' FL learning setting and the source of the pronunciation problem need to be analysed in depth to desuggest this kind of inhibitions. In brief, learners should not only be prepared to rehabilitation but also encouraged to make a concerted effort.

One of these pronunciation problems for non-native adult learners of English language is the English contrasts "ash" $/ \mathfrak{a} /$ and wedge $/ N /$ vowel phonemes. Both the phonetic symbol $/ N$ and the sound are commonly referred to as either a wedge, a caret, or a hat. It is an open mid-back unrounded vowel phoneme as in the words cub $/ \mathrm{k} \wedge \mathrm{b} /$ and dub $/ \mathrm{d} \wedge \mathrm{b} /$. The 
English "ash"/æ/ vowel phoneme, on the other hand, is a front open low unrounded short vowel as in the well-known words bad $/ \mathrm{bæd} /$ and cat $/ \mathrm{kæt} /$. This phoneme is problematic to pronounce in many wide spoken languages such as Turkish, however (see Figure 1).

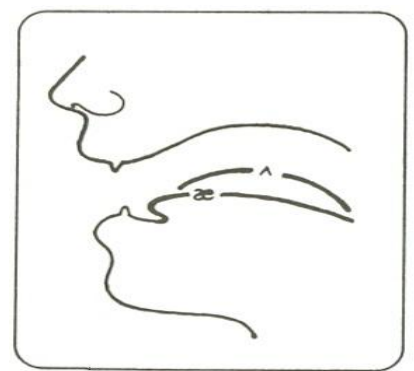

Figure 1: Aspiration of "ash"/æ/ and wedge $/ N$ vowel phonemes

Therefore most Turkish adult learners of English language articulates /æ/ vowel phoneme like /e/ as in pan / $\mathrm{p}^{*} \mathrm{e} \mathrm{n} /$ and not as / pæn/ (see Figure 2).

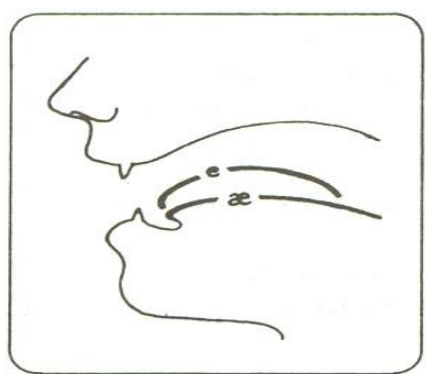

Figure 2: Aspiration of "ash"/æ/ and /e/ vowel phonemes

Nevertheless, a rehabilitation method is required to verify the effectiveness of these assumptions. Although the rareness of such methods makes the situation harder, the audio-articulation method by Demirezen (2003) seems to be a valuable pronunciation teaching method which asserts to cure fossilized mistakes of adult learners, especially of Turkish learners of English language. This kind of problem does not only harm the communicative competence of Turkish adult learners but also teacher trainees, novice teachers and teachers-on-the-job. For example mispronunciation causes sometimes serious interpretation and therefore interaction problems. To avoid such troubles, pronunciation rehabilitation cures need to be applied to such learners and teachers. Therefore, in this study, /æ/ and $/ N$ vowel phoneme articulation problems of Turkish FL teachers will be examined and a remedy will be produced by the Audioarticulation Method to cure such problems on pronunciation.

\section{METHOD}

\section{A. Participants in the Study}

The study was carried out in the FL department at a Turkish university by participating of 16 lecturers. Five males and eleven females enrolled in the cure programme which lasted a total course hour. The age of participants varied from 25-32 and their teaching experience two to nine years. They all have scored 85 and above on foreign language proficiency examination for state employees. Finally, all of the lecturers are graduates of ELT departments in Turkish universities and they have never been in an English speaking country to improve their language skills.

\section{B. The Problem of the Study}

The English contrasts "ash" /æ/ and wedge / $\wedge$ vowel phonemes are crucial articulation problems for Turkish teachers and learners who have learned the target language after the critical age period. That is, as stated earlier, especially the "ash"/æ/ phoneme is challenging Turks and therefore most Turkish adult learners of the English language articulates /æ/ vowel phoneme like /e/ as in pan /p*e n/ and not as / pæn/. This kind of articulation problem requires specific attention especially in teacher training since these mistakes harm the validity and professional status of the FL teachers.

\section{Research Design \& Data Analysis}

In the field of ELT diagnostic tests are designed to recognize specified aspects of a language. That is, with a narrow scope of analysis, these tests aim to identify a specific condition or problem. For example, as it is in this case, a test in pronunciation can diagnose the phonological features of the English language and offer the researcher to pinpoint the pronunciation problems of non-native FL teachers. In the same line of thinking, participants in this study were directed to read aloud a passage titled "Fat Pat" while they were tape-recorded (see Appendix). The passage used in this study as 
a diagnostic test contained $43 / \Re /, 5 / \wedge$ and $14 / \mathrm{e} /$ vowel phonemes to check whether participants could identify and pronounce the phonemes in an accurate way. After the articulation problems had been recognized, a treatment phase was applied to cure or defossilize participants' pronunciation problems (see the treatment phase). That is, a fossilized mistake eraser called the audio-articulation method was implemented to remedy the fossilized pronunciation mistake on /æ/ vowel phoneme of the British English language which lasted only a total class hour to see the immediate effects. Two weeks after the treatment, the passage used as a diagnostic test was directed to the participants for the second time to see the effects of the treatment phase.

In conclusion, the performances of the participants, i.e. the correct pronounced phonemes, were evaluated and scored by a native speaker of the English language. As the form of data is quantitative, the method of analysis is statistical and the manner of data collection is experimental, the scores got from the pre- and post tests are compared statistically to see whether there is any significant difference. Since the case was repeated measurements on a single sample to assess whether their population means differ, the Wilcoxon signed-rank test was used to display the significance of the study.

\section{An ApPlication of the Audio-ARticulation Method}

One of the important problems in foreign and second language classes has been to apply the construct of motivation. It is not our present issue but it is very important to take learners' attention on the subject matter. So, the motivation and warm-up section should take a couple of minutes. Later on, a variation on Audio-Lingual Method teaching is based in the procedure most often referred to as 3P approach which stands for Presentation, Practice, and Production. Shortly explained by Harmer (2001), in this procedure the teacher introduces the language to be taught, the students practice the language using accurate reproduction techniques such as individual or choral repetitions. Later the learners, using the new language, make sentences of their own.

\section{A. Preparation of a Corpus}

In accordance with the principles of the audio-articulation method, the researcher prepares a corpus about 100 words pertaining this fossilized problem-causing phoneme and develops all of his/her exercises from this corpus.

The words cited in the corpus listed by Nielsen and Nielsen in 2010 are generally exhibiting /æ/ and $/ \wedge /$ sounds phonemically. According to Demirezen (2006) the researcher's exhortations of the words in the corpus and his employment of the other drilling techniques like minimal pair contrasts, chain drills, substitution drills, repetition drills, inflection drills, replacement drills, restatement drills, completion drills, transposition drills, expansion drills, contraction drills, transformation drills, integration drills, rejoinder drills, restoration drills, question-answer drills, language games and many other creative exercise types, are all of great help in this respect.

The researcher does exhortations on the corpus words and gets them to be repeated without boring the students, bearing the time limitation in mind.

\section{The Corpus}

$\mathrm{cab} / \mathrm{kæb} /$ - cub $/ \mathrm{k} \wedge \mathrm{b} /$

$\mathrm{nab} / \mathrm{næb} /-\mathrm{nub} / \mathrm{n} \wedge \mathrm{b} /$

$\mathrm{stab} / \mathrm{stæb} /$ - stub /st $\wedge \mathrm{b} /$

$\mathrm{dad} / \mathrm{d} d /$ - dud $/ \mathrm{d} \wedge \mathrm{d} /$

calf /kæf/ - cuff $/ \mathrm{k} \wedge \mathrm{f} /$

hag /hæg/ - hug / h^g/

slag /slæg/ - slug /sl^g/

drag /dræg/ - drug /dr $\wedge$ g/

clang /klæy/ - clung $/ \mathrm{kl} \wedge \mathrm{y} /$

sang /sæy/ - sung /s^y/

pack $/ \mathrm{pæk} /$ - puck $/ \mathrm{p} \wedge \mathrm{k} /$

tack /tæk/ - tuck /t^k/

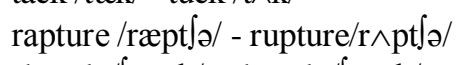

shrank / Jræyk/ - shrunk / $\mathrm{r} \wedge \mathrm{jk} /$

$\mathrm{ma}$ am $/ \mathrm{mæm} /$ - mum $/ \mathrm{m} \wedge \mathrm{m} /$

ham /hæm/ - hum /h^m/

$\mathrm{cram} / \mathrm{kræm} /$ - crumb /kr^m/

fan /fæn/ - fun /f $\wedge$ n/

task /tæk/ - tusk /t $\wedge$ sk/

cap /kæp/ - cup /k^p/

bass /bæs/ - bus /b^s/

dank /dæyk/ - dunk / $\wedge \mathrm{jk} /$

ran /ræn/ - run /r^n/

hatch $/$ hænt $\mathrm{f}$ - hutch $/ \mathrm{h} \wedge \mathrm{t} \mathrm{f} /$

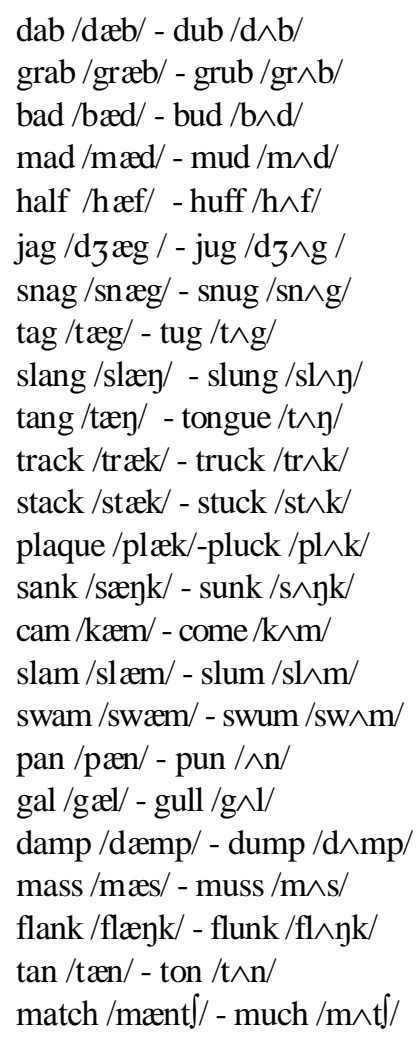

\author{
flab /flæb/ - flub /fl^b/ \\ $\mathrm{tab} / \mathrm{tæb} / \mathrm{tub} / \mathrm{t} \wedge \mathrm{b} /$ \\ $\mathrm{cad} / \mathrm{kæd} /$ - cud $/ \mathrm{k} \wedge \mathrm{d} /$ \\ gassed /gæsd/ - gust /g^sd/ \\ bag /bæg/ - bug /b^g/ \\ lag /læg/ - lug / $/ \wedge \mathrm{g} /$ \\ $\mathrm{rag} / \mathrm{ræg} /$ - rug $/ \mathrm{r} \wedge \mathrm{g} /$ \\ hang /hæy/ - hung $/ \mathrm{h} \wedge \mathrm{y} /$ \\ rang /ræy/ - rung /r^y/ \\ branch /brænt $\mathrm{J}$ - brunch /br $\wedge$ nt $\mathrm{f} /$ \\ sack/sæk/ - suck /s^k/

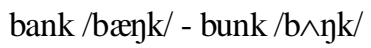 \\ staff /stæf/ - stuff /st $\wedge$ / \\ mask /mæk/ - musk /m^sk/ \\ $\mathrm{dam} / \mathrm{dæm} /$ - dumb /d $\wedge \mathrm{b} /$ \\ $\mathrm{ram} / \mathrm{ræm} /$ - rum $/ \mathrm{r} \wedge \mathrm{m} /$ \\ ban /bæn/- bun /b^n/ \\ span /spæn/ - spun /sp^n/ \\ gravel/grævəl/ - grovel /gr^vəl/ \\ lamp /læmp/ - lump /l^mp/ \\ patter /pætə/ - putter /p^tə/ \\ plank /plæyk/ - plunk /pl $\wedge$ jk/ \\ sadden /sædən/ - sudden /s^dən/
}


sand /sænd/ - sunned /s^nd/ dance /dæns/ - dunce /d $\wedge$ ns/ rabble /ræbəl/ - rubble /r $\wedge$ bəl/ paddle /pædəl/ -puddle /p^dəl/ jangle /dzængəl/ - jungle /dz^ngəl/ clamp /klæmp/ - clump /kl $\wedge \mathrm{mp} /$ stamp /stæmp/ - stump /st八mp/ pamper /pæmpə/ - pumper /p^mpə/ graph /græf/ - gruff /gr $\wedge f$ / hash /hæl/ - hush $/ g \wedge \mathrm{d} /$ flash/flæe/ - flush /fl $\wedge \mathrm{d} /$ mash/mæl/ - mush $/ \mathrm{m} \wedge \mathrm{J} /$ brash/bræ $\int /$ - brush $/$ br $\wedge \int /$ thrash $/ \theta \mathrm{r} \mathfrak{d} /$ - thrush $/ \theta \mathrm{r} \wedge \mathrm{J} /$ shack / $/$ æk/ - shuck $/ \int \wedge \mathrm{k} /$

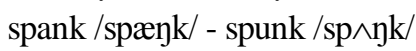

stand /stænd/ - stunned /st^nd/

badge /bædz/ - budge /b^dz/

ramble /ræmbəl/ - rumble /r^mbəl/

bangle /bængəl/ -bungle /b^mgəl/

ankle /ænkəl/ - uncle /^nkəl/

ramp /ræmp/ - rump /r^mp/

adder /ædə/ - udder / $\wedge$ də/

flatter /flætə/ - flutter /fl $\wedge$ tə/

gash $/$ gæ $/$ - gush $/ g \wedge \int /$

lash /læJ/ - lush $/ 1 \wedge \mathrm{J} /$

slash $/$ slæ $\int /$ - slush $/ \operatorname{sl} \wedge \int /$

rash $/ \mathrm{ræ} \int /$ - rush $/ \mathrm{r} \wedge \mathrm{J} /$

crash $/ \mathrm{kræ} \int /$ - crush $/ \mathrm{kr} \wedge \mathrm{d} /$

back /bæk/ - buck /b^k/

lack /læk/ - luck $/ \mathrm{l} \wedge \mathrm{k} /$

drank /dræyk/ - drunk /dr^ $\mathrm{yk} /$

\section{B. Practicing the Topic}

The pronunciation problem-causing $/ \mathfrak{e} /$ and $/ \wedge /$ is practiced in class by getting the tongue twisters repeated by the students individually or chorally. The researcher prepares tongue twisters from the corpus or searches the well-known ones from the internet and does necessary techniques mentioned earlier in single or group repetition without boring the learners.

There are many effective exercises to implement the tongue twisters as stated earlier; however, the researcher preferred the expansion drills and recognition exercises. Since the expansion drills provide learners with an idea of the order of occurrence of the words in a sentence and how the sentences could be built up by help of the related sounds and the recognition exercises help learners to identify words by their appearance and improve their pronunciation. In the treatment phase, the researcher makes the necessary corrections in the wrong articulations without boring and demoralizing the participants.

\section{Expansion drills.}

1. cab

flabby cab

Don't dab the flabby cab

2. the cubs

the cubs on the cabs

the cubs on the cabs are lined up

3. nab

nabbed my apple

he suddenly nabbed my apple

4. batter

butter in the batter

put real butter in the batter

\section{Recognition exercises.}

Researcher: Dear colleagues, I'm going to give you some words now, if you hear the /æ/ sound you say one, or if you hear the sound $/ N$, you say two. Here is an example:

R: Derya, which sound do you hear in the word "clamp"?

Derya: One!

R: Good. Thank you, Derya. Fatih, tell me, which sound do we hear in the word "huff "?

Fatih: Two.

R: Very good, Fatih. Burcu, which sound is heard in the word "ran "?

Burcu: Two!

R: Well done, Burcu, thank you. (Practice goes on as the time limit allows.)

Part two:

R: Dear friends, now I'm going to give you two words. If you hear the /æ/ sound you say one, if you hear the sound $/ N$, you say two, or you say three if you here the /e/ sound. Here is an example:

R: Fatma, which sounds do you hear in the words "dad", "ded" and "dud"?

Fatma: One-three-two!

R: Correct, thank you Fatma. Seval, "gust","guest" and "gassed"?

Seval: Two -three -one!

R: Very Good, Seval. Tuba, "stab", "stub" and "step"? 
Tuba: One-two-three!

R: Well done, Tuba, thank you. (The practice goes on in accordance with the time limit.)

\section{Giving the Rule}

The vowels on Figure 3 are so-called primary cardinal vowels and these are the vowels that are most familiar to the speakers of most European languages. For example, cardinal vowel no. 1 has the symbol [i], and is defined as the vowel which is as close and as front as it is possible to make a vowel without obstructing the flow of air enough to produce friction noise. However, cardinal vowel no. 5 has the symbol $[\alpha]$ and is defined as the most open and back vowel that it is possible to make.

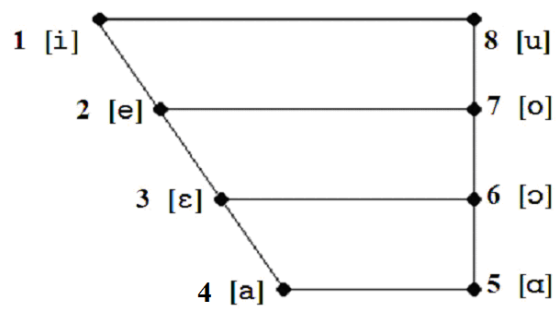

Fig. 3: Primary cardinal vowels

When many learners hear these vowels, they find that they sound strange and exaggerated however, it must be remembered that they are extremes of vowel quality. When we are familiar with these extreme vowels, then we have learned a way of describing, classifying and comparing vowels. For example, as seen in Figure 4, we can say that the English ash vowel /æ/ (the vowel in 'cat') is front, but not quite as open as cardinal vowel no. 4 [a]. The lips are slightly spread.

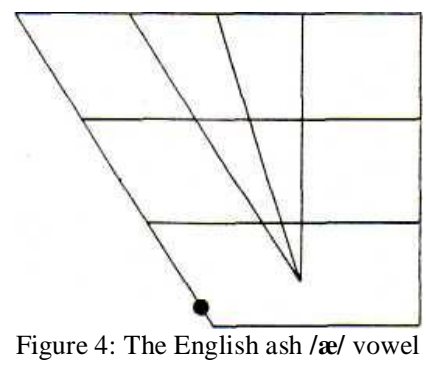

On the other side, the wedge vowel $/ \wedge /$ ( in 'but' and 'some') is a central vowel, and figure 5 shows that it is more open than the half-open tongue height. The lip position is neutral.

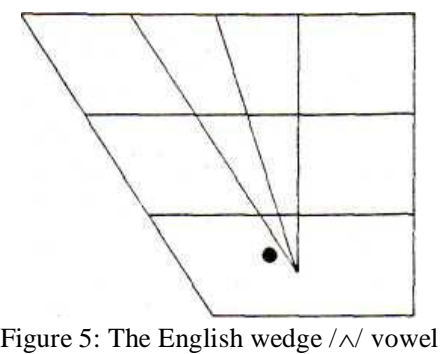

\section{Doing Further Exercises}

Using minimal sentences. The researcher's exhortations on the following statements are crucial, and he must get them to be repeated by the students in form of single or in unison without boring the students.

- I called her BACK/BUCK.

- It is a BRANCH /BRUNCH.

- It's not MAD/MUD.

- It's not my DAD/DUD.

- Hang the CAP/CUP on the hook.

- Don't step on that BAG/BUG.

- It was a real SLAM/SLUM.

- It was hard to catch that BASS/BUS.

- It was one of the elephant's TASKS/TUSKS. 
Using sentences with contextual clues. The researcher's exhortations on the correct articulation of the following sentences raise the consciousness of the students towards the problem-causing sound.

- Cause of the GUST Hans was GASSED

- Don't JANGLE in the JUNGLE

- PACK the PUCK in the SACK

- BUDGE the BADGE

- Follow the TRACK with your TRUCK

- TUCK the TACK in the BAG

- My HAT is in that HUT.

- The city DUMP is often DAMP.

- Ducks PADDLE in this PUDDLE.

- She makes RUGS from old RAGS

Using problem-sound concentrated exercises. The following sentences are used as exhortations by the researcher, and learners repeat them individually or chorally. If there are videoed or tape recorded repetitions of them, it is even better if they are shown to the students. The researcher tries to use meaningful tongue twisters and related exercises in this respect since, asserted rightly by Linse (2003), using non-meaningful tongue twisters are full of fun.

- Don't RANG the ring of my UNCLE who HAD a HAT AND a CAB.

- My DAD said THAT my MA’AM CAN RAN.

- He HAD a SUDDEN heart ATTACK, BUT HADN'T SADDENED me.

The researcher ends the lesson by directing them to make as much practice as they can do in front of the mirror or listening foreigners on TV.

\section{E. Giving Assignments}

The Teacher can give the following issues as homework:

1 . Restudy all of the exercises.

2. Prepare 3 clear-cut tongue twisters as exemplified.

3. Prepare 5 minimal sentences.

4. Prepare 3 sentences with contextual clues.

5. Prepare 3 problem-related exercises, tape, and bring them to class.

6 . Write a dialogue including the $/ æ /$ and $/ \wedge /$ vowel phonemes.

7. Write a paragraph (in 200 words) by using the words given in the CORPUS.

\section{FINDINGS AND RESUltS}

In this study, it was aimed to compare non-native English teachers' articulation performances through a diagnostic test carried out before and after treatment. Their performances were evaluated and scored by a native speaker of the English language before and after treatment to test the results statistically. As known, the Wilcoxon signed-rank test is a non-parametric statistical hypothesis test used when comparing two related samples or, as it is in this case, repeated measurements on a single sample to calculate whether their population means differ (i.e. it's a paired difference test). As seen in tables 1 \& 2 , there is a significant relationship or difference between the performances of the participants when compared before and after treatment $(\mathrm{z}=-3.527$, $\mathrm{p}<.05)$. That is, the cure programme applied in the treatment phase affected participants' pronunciation in a positive way and help them to rehabilitate their articulation problem.

TABLE 1

WILCOXON SIGNED RANKS TEST

\begin{tabular}{|c|c|c|c|c|}
\hline & & $\mathrm{N}$ & Mean Rank & Sum of Ranks \\
\hline \multirow[t]{4}{*}{ postscore - prescore } & Negative Ranks & $0(\mathrm{a})$ & 00 & ,00 \\
\hline & Positive Ranks & $16(b)$ & 8,50 & 136,00 \\
\hline & Ties & $0(\mathrm{c})$ & & \\
\hline & Total & 16 & & \\
\hline
\end{tabular}

TABLE 2

TEST STATISTICS(B)

\begin{aligned} & \hline $\mathrm{Z}$ postscore - prescore \\ & \hline Asymp. Sig. (2-tailed) $-3,527(\mathrm{a}) \\ &$\hline a Based on negative ranks. \\ & b Wilcoxon Signed Ranks Test \end{aligned}




\section{CONCLUSION AND RECOMMENDATIONS}

The critical period hypothesis asserts that there is a biologically-determined period to acquire a language and after this period language acquisition becomes much more difficult. Although, there is no empirical proof for this argument, the study of accent in second language acquisition seems to be strong evidence especially in explaining why most of the older learners could not reach a native-like accent. For example, the well-known Kissenger effect is an important sample since Kissenger had a German accent while speaking English but had also a magnificent and fluent control on the English language.

However, although it is very hard to change learners' pronunciation and teach them a native-like accent after such a biologically-determined period, it does not mean that there is no cure for deficiencies in pronunciation. For that reason, this study does not have the aim to attack or assault the critical period hypothesis, but rather suggest the re-examination of the well-known belief. That is, this negative belief needs to be reconsidered since this study has investigated the pronunciation problems of older language learners such as Turkish teachers of English language on-the-job and evidenced that the pronunciation deficiencies can be rehabilitated and cured. As asserted rightly by Acton (1984), people who are going to work with the language at an advanced level as teachers or researchers need a deeper understanding provided by the studies of related areas of linguistics especially the study of phonetics and phonology.

Doubtlessly, since most teachers and teacher trainees are aware and agree that explicit pronunciation is an essential part of teacher training, as Demirezen (2005) has also mentioned, the theoretical and practical material in similar studies is necessary for anyone who needs to understand the principles regulating the use of sounds in spoken English. Additionally, under the light of the in-class activities submitted throughout this study, the impression is that the fossilized sort of errors can be cured by means of the peculiar method put forth by Demirezen. Therefore, this paper, first of all, suggests such cure programs for Turkish teachers on-the-job, to teacher trainees and finally to material developers and publishers, and recommend highly to enrich the language teaching materials with explicit pronunciation exercises for adult learners using this and similar cure programs.

\section{APPENDIX}

\section{Diagnostic Test}

Fat Pat

Pat was so fat that she made a bet with Lenny the vet. She bet him that she could get a fat cat and a wet rat under her hat. Unfortunately, the fat cat was not Fat Pat's pet, and it sat on the rat. The rat naturally ran away. Poor fat pat. She lost her bet.

Lenny was a vet and one day he met Fat Pat's wet rat. The rat had been sat upon by Pat's fat cat while it was under Pat's hat. That rat was in bad shape. Lenny had to let that rat have a little nap.

\section{REFERENCES}

[1] Acton, W. (1984). Changing fossilized pronunciation. TESOL Quarterly 18.1, 71-85.

[2] Colombo, J. (1982). The critical period concept: Research, methodology, and theoretical issues. Psychological Bulletin 91, 260275.

[3] Demirezen, M. (2003). İngilizce'nin THETA sesbiriminin (peltek-t) Türkler için çıkardığı sesletim sorunları [The pronunciation problem of /d/ and /ð/ for Turks and their solutions]. Tömer Dil Dergisi 120, 57-71.

[4] Demirezen, M. (2005). Rehabilitating a fossilized pronunciation error: The /v/ and /w/ contrast by using the audio articulation method in teacher training in Turkey. Journal of Language and Linguistic Studies 1.2, 183-192.

[5] Demirezen, M. (2006). Flapping in North American pronunciation: Case 1 the change of /t/ and /d/ into /D/ in pronunciation. Journal of Language and Linguistic Studies 2.1, 87-100.

[6] Diagnostic test. http://international.ouc.bc.ca/pronunciation/eslp025unit08.pdf (accessed 21/2/ 2010)

[7] Harmer, J.(2001). The practice of English language. Essex, England: Longman.

[8] Lenneberg, E. (1964). The capacity for language acquisition. In Fodor, J. A. \& J.J. Katz (Eds.), The structure of language (pp.579-603). Englewood Cliffs, NJ: Prentice Hall.

[9] Linse, C. (2003). Twisting tongues: Tongue twisters in the classroom. Modern English Teaching, 12 (4), 26-28.

[10] Nilsen, Don L. \& A. P. Nilsen (2010). Pronunciation contrasts in English. New York: Regents Publishing Company.

[11] Selinker, L. (1972). Interlanguage. IRAL 10.3, 209-31.

[12] Wells, J.C. (2000). Longman Pronunciation Dictionary New Edition.

Ayhan Kahraman is an Assistant Professor in the Western Languages and Literatures Department at Dumlupınar University, Faculty of Arts and Sciences, Kütahya-Turkey. He received his Ph.D from the ELT department at Hacettepe University, AnkaraTurkey in 2009. He also received a German certificate from the German Culture Institute in 1997 and a Certificate of Training from Dumlupinar University. He is currently offering courses at the graduate and undergraduate level at Dumlupinar University. His research interests include ESP, teacher training, individual differences in foreign language teaching, and general issues encountering in ELT. 